\title{
THE EDUCATIONAL VALUE AND TEACHING STRATEGY IN "FREEDOM WRITER" BY RICHARD LAGRAVENESE
}

\author{
Ayu Kartika Listiyana, ${ }^{1}$, \\ Rifari Baron 2, \\ Universitas Indraprasta PGRI Jakarta \\ e-mail: ayukartikalistiyana@gmail.com ${ }^{1}$ \\ e-mail: rifaribaron@yahoo.com ${ }^{2}$
}

\begin{abstract}
This research aims to analyze the educational value and teaching strategy in the "Freedom Writer" film by Richard Lagravenese. Based on the theories of educational value and teaching strategies, there are four primary points to analyze: 1) How is Educational Value in 'Freedom Writer Film' by Richard Lagravenese? 2) What are the Teaching Strategies in 'Freedom Writer Film' by Richard Lagravenese? 3) There are eleven kinds of educational value that appear in "Freedom Writer" by Richard Lagravenese based on Linda, they are honesty, courage, peaceability, self-reliance and potential, self-discipline and moderation, loyalty and dependability, respect, unselfishness, and sensitivity, kindness \& friendliness, justice and mercy, and love. 4) There are five kinds of teaching strategies that appear in Richard Lagravenese based on Brown; they are content-based instruction, theme-based instruction, experiential learning, episode hypothesis, and task-based teaching.
\end{abstract}

Keywords: educational value, teaching strategy, film.

\section{Introduction}

Education is a device that provides people with information, ability, procedure, information, empowers them to know their privileges and obligations toward their family, society just as the country. People can get new insight from education. Thus, this improves a person's odds throughout everyday life and assists with handling neediness. In addition, education as a push to enlighten human savvy ought to be run because of qualities that quandary education itself, not the outside educational world. There is a move in characterizing training which drives us to an inclination for the genuine importance of education. Michael $(2009$, p.2) claimed that education is imparted to knowledge, to inculcate skills to fit people in life, above all, to help young people develop as whole human beings, equipped to lead a good life. In this sense, for some, education will be a significant job to improve their ability and quality themselves.

Therefore, this represents the individual characteristics that decide to realize and guide our activities, how we treat ourselves and other people, and our cooperation with our general surroundings. This will provide the general rules to direct. Education becomes an integral part of society because it teaches interacting with others, especially children. Moreover, this also teaches how to behave in group and one-on-one situations. According to Novak \& Gowin (2002:111) claimed that "educational value is a change of the nature of experience that engages learners to offer significance to themselves and their reality, and the estimation of education must be decided by its capacity to bring an instructive result." In line with, Ulpa (as cited in Saputra, 2012:22) said that educational value in the basic definition implies the restriction of everything which instruct to development, including goodness and disagreeableness, to be helpful for people's life which is obtained from the instructive procedure.

Moreover, the educational value becomes a significant aspect that assumes a tremendous role in the modern era, industrialized world. People need a decent education value to have the option to get into this competitive world. In this case, the instructors bring out or creative potential. This is a procedure of living and not a preparation for future living. 
The purpose of instructors, particularly educators, is to assist students learn by giving them information and setting up a circumstance in which students can study effectively. Student inspiration can be upgraded when the motivation behind evaluation is advancing student learning, and this is conveyed to students by what the instructor state and do. During being an effective instructor, the teacher needs to gain from any assets or references that give the best approach to educate successfully. One way is to use films that contain instructive information and qualities as a reference. Some of these films have a few characters that have their one-of-a-kind and new instructing ways demonstrated to change the learners better in the future effectively. Before the instructor encourages students in the classroom, the instructor will create the materials and arrange how to make students easier to get information. Moreover, it also creates the material to make students accomplish the course objectives. Students are more likely to recall information if the instructor can clarify the material. In this way, the instructor should consider the encouraging technique before the instructor teaches students then apply it in the classroom based on the fittingness of the teaching strategy.

The instructor needs to comprehend the procedure used for the learners. Best instructors attempt to locate the appropriate methodology, strategy, and procedures to make a learning situation that fits the learners needed. Moreover, effective instructors consistently sneak around for new and exciting instructing techniques to keep the learners engaged and inspired. Herein, in this case, need a good teaching technique from an instructor during a learning situation. According to Harumni (2009, p.11), the procedure is done to actualize the strategy. It implies that the procedure is the way the instructor does in this way. The strategy can be going on successful and effective. Using strategy is constantly identified with the methodology and technique. Thus, it very well may be inferred that teaching strategy is the way the instructor actualizes a technique specifically.

Furthermore, teaching strategies, also called instructional techniques, are strategies that instructors use to convey course material in manners that keep understudies drawn in and rehearsing diverse abilities. An educator may choose diverse training systems as per unit point, grade level, class size, and homeroom assets. Many kinds of instructional methodologies are used to accomplish learning and teaching objectives and sustain various learners.

Overall, teaching strategy is the technique used to pass on data to your learners effectively. Abiola (2005, p.11) claimed an undeniable connection between an instructor's system of learners' attitude to the instructing and learning in the classroom. This implies that the expected performance of learners depends on instructors' strategies of showing the subject and attitude.

Furthermore, Kitsner (2015: 177) claimed that "teaching strategies is one significant part of the aspect of self-managed learning." Herein, instructors must locate the best strategies to meet each learner in self-managed learning. In case, teaching strategies must address the issues of the learners. Learners may have learning inabilities or endure because of the language barrier. Thus, the instructor needs to assemble the learners' confidence about examining since fearless is one of the significant factors influencing the learners' accomplishment in studying. Moreover, teaching strategies become the instrument of accomplishing the set objectives. The present impression of instructing depends on the humanistic way to deal with training and, in addition to other things, the standards of basic correspondence didactics.

Finding harmony between straightforward guidelines and arranging the exercises of the classes and groups of the learners is significant. The instructor needs to direct and deal with the class to make the best educating and learning circumstances. Instructors can use a few media to help their showing learning procedure, for example, video, film, or picture. Significantly, the film is one of the excellent media for helping the learning process. Hence, the film comes with numerous classifications, particularly fiction, horror, action, parody, drama, science fiction, memoir. One of the films that have excellent references for education progression is "Freedom Writers" film. At this point, this condition is shown in the „Freedom Writer" film. Erin Gruwell, the new English instructor in the Wilson School, confronted some issues, and for example, the learners can focus on the classroom since they are comprised of diverse backgrounds.

At first, the learners very much hate Erin Gruwell as an instructor. The learners cannot accept the educator. In general, the issue with the educational establishment is the educating-learning process and school strategy Erin Gruwell needs to face as a new instructor. 
Further, Richard LaGravenese is the director of the freedom writer film. He is the child of a taxi driver. On October 30, 1959, he was born in Brooklyn, New York. Moreover, he is an American screen author and periodic movie director. The film is adopted from on true story, The Freedom Writers Diary, by Erin Gruwell and her students. This film was released on January 5, 2007, in California, United States of America. The running time or the length of this film is around 122 minutes or one hour and twenty-two minutes.

The 'Freedom Writer' talks about the issues in racism that occurred in Long Beach, California. This film starts with the Rodney Ruler revolts that occurred in Los Angeles in 1992. The main story originates from Eva, a young Latino lady whose companion suddenly died. Furthermore, the police bring and catches her dad, who attempts to help her companion in the jail. In Long Beach, the public is isolated into a few Asian, Dark, Latino, and White groups. They executed each other for their race, esteem and pleased their gangs. Their life is not quiet because they can be competitors by different classes at whatever point and wherever. The learners have their self-classes and selfexperience, which impact their character. Individuals originate from various societies framed by various standards, qualities, philosophies, and segments. The difference in societies makes a probability wherein individuals may confront challenges in understanding others' expectations.

In this manner, social comprehension in connection is expected to accomplish effective intercultural correspondence. The absence of social mindfulness can cause misconception, which influences the connection progression between the members. The misconception can be as previously established inclinations about the members. This appears by their behaviours, such as anarchism, not respecting one another, bullying one another, and being a loner. They carry on like that since they got and saw impolite conduct in the past. This phenomenon makes nearly all the learners be a criminal. They do not regard different classes. They generally wreck and censure one another. They are too pleased with their groups. It makes the learners frequently battle with other criminals.

Furthermore, the 'Freedom Writer' film has gotten a few awards. This film won a Humanity Price Award for including film classification in 2007 and Richard LaGravenese as a beneficiary. This film got named in Image Award for extraordinary writing in a movie (showy or TV) class 5 of every 2008 Richard LaGravenese as a beneficiary.

The researcher chooses this film not only because it has an excellent rating or best award yet but also because it has the anecdote about a young educator Erin Gruwell inspires her class of indanger learners to learn resilience, apply themselves, and seek after training past secondary school. Also, this film depends on a simple story that shows the racial clash among the races.

In addition, the film has an exciting conflict from the battle of an instructor to racism among the learners. The film shows that each conflict is associated as the story advances. The film shows how the principal character Erin Gruwell must battle to figure out how to end bigotry in her group. Racism in this film turns into the primary conflict and makes the film interesting. Also, the social issue of the racial clash is reflected in this film. Almost all the learners got the terrible experience because of the distinctive of their race. They lost their family and their companions. This condition makes the terrible in the learner and makes them keep themselves and their classes. Hence, the film's substance depicts an English instructor who needs to make agreeable circumstance in the study hall although the learners from various backgrounds.

The film's substance comprises some English instructing strategy, discuss about scholarly and value for the learners. Numerous scenes in the study hall currently educate English in the Middle English Class. Hence, the English instructor uses many training methods in learning activities. Therefore, the researcher chooses this film not only because it has an excellent rating or best award but also because it has the anecdote about a young educator Erin Gruwell inspires her class of in-danger learners to learn resilience, apply themselves, and seek after training past secondary school. Also, this film depends on a true story that shows the racial clash among the races.

\section{Method}

The approach of this research is descriptive qualitative research. According to Endraswara (2004:16) claimed that "descriptive method is described by words or figures if necessary, and it does not describe the numerical analysis." This is actualized because the information analysis is introduced 
INFERENCE: Journal of English Language Teaching

Vol. 4, No. 3, December 2021 - March 2022

p-ISSN: 2615-8671

e-ISSN: 2615-868X

descriptively. This can be interpreted as a problem-solving procedure that is investigated by describing the state of the subject or object in the study can be in the form of people, institutions, communities, and others currently based on the facts.

As an analysis, the focus of the research is educational value and teaching strategy in the film Freedom Writer by Richard LaGravenese with the approach of Linda through her educational value theory and the approach of Linda with her teaching strategy theory. The sub-focus of the research is based on its educational value objects such as the value of being and value of giving. Furthermore, the sub-focus of the research is also based on its teaching strategy objects such as content-based instruction, theme-based instruction, experiential learning, the episode hypothesis, and task-based teaching from Brown's theory.

In this research, the researcher uses some instruments to analyze the focus and sub-focus of the research. The instruments of educational value analysis use-value of being and value of giving. These two instruments are the base to analyze and interpret each scene in Freedom Writer Film. Additionally, the instruments of teaching strategy analysis use content-based instruction, theme-based instruction, experiential learning, the episode hypothesis, and task-based teaching.

\section{Results and Discussion}

From the dialogues that have been collected, the researcher can present the percentage of educational value and teaching strategy in Table 1 and Table 2.

1. The educational values are found for about 16 data of educational values in 'Freedom Writer' by Richard LaGravenese.

Table 1 Educational Value

\begin{tabular}{|c|c|c|}
\hline No & Educational Values & Percentage \\
\hline \multicolumn{3}{|c|}{ Value of Being } \\
\hline 1 & Honesty & $12,5 \%$ \\
\hline 3 & Courage & $12,5 \%$ \\
\hline 4 & Peace-ability & $6,25 \%$ \\
\hline 5 & Self-discipline and Moderation & $12,5 \%$ \\
\hline 6 & Fidelity and Chastity & - \\
\hline & Value of Giving \\
\hline 1 & Loyalty and Dependability & $6,25 \%$ \\
\hline 2 & Respect & $6,25 \%$ \\
\hline 3 & Love & $12,5 \%$ \\
\hline 4 & Unselfishness and sensitivity & $12,5 \%$ \\
\hline 5 & Kindness and Friendliness & $6,25 \%$ \\
\hline 6 & Justice and Mercy & $6,25 \%$ \\
\hline
\end{tabular}


INFERENCE: Journal of English Language Teaching

Vol. 4, No. 3, December 2021 - March 2022

p-ISSN: 2615-8671

e-ISSN: 2615-868X

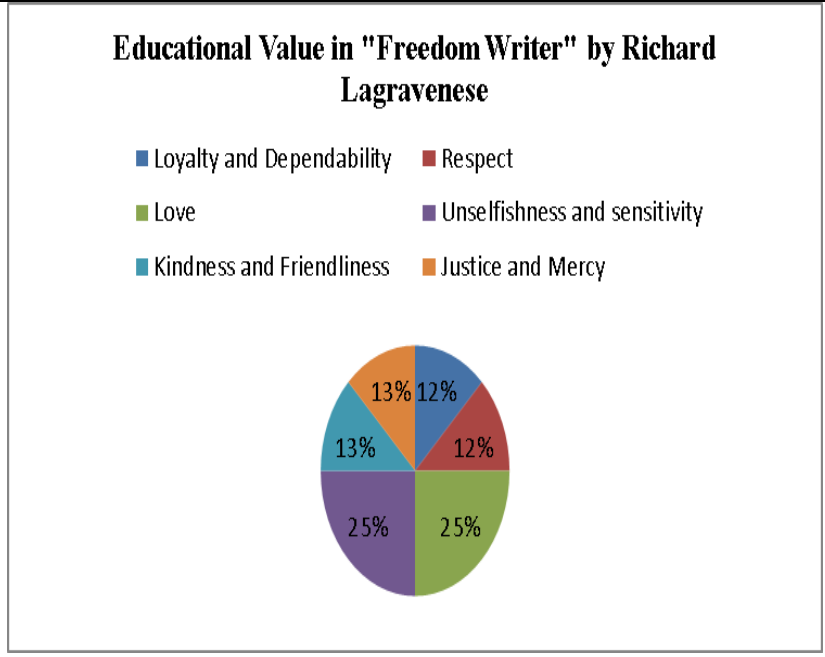

Figure 1. Educational Value

2. The researcher found about 10 data of teaching strategies in 'Freedom Writer' by Richard LaGravenese.

Table 2

Teaching Strategy

\begin{tabular}{|c|l|c|}
\hline No & \multicolumn{1}{|c|}{ Teaching Strategies } & Percentage \\
\hline 1 & Content-based Instruction & $30 \%$ \\
\hline 2 & Theme-based Instruction & $20 \%$ \\
\hline 3 & Experiential Learning & $10 \%$ \\
\hline 4 & The Episode Hypothesis & $10 \%$ \\
\hline 5 & Task-based Teaching & $30 \%$ \\
\hline
\end{tabular}

\section{Teaching Strategy in "Freedom Writer" by} Richard Lagravenese

content-based Instruction $\mathbf{m}$ Theme-based Instruction

Experiential Learning $\quad$ The Episode Hypothesis

Task-based Teaching

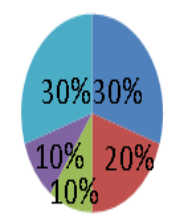

Figure 2. Teaching Strategy 
Educational Value

After analyzing the data found in "Freedom Writer," the writer can conclude that the educational value emerges in "Freedom Writer": Most data about educational values are shown by an English teacher named Erin as the main character. Thus, she shows that most educational values are in Freedom Writers film through the value of being and giving. The data of educational values are 8 values of being such as honesty $12,5 \%$; courage $12,5 \%$; peace-ability $6,25 \%$; self-reliance and potential 6,25\%; self-discipline and moderation $12,5 \%$; and fidelity and chastity $0 \%$.

Furthermore, eight values of giving such as loyalty and dependability $6,25 \%$; respect $6,25 \%$; love 12,5\%; unselfishness and sensitivity 12,5\%; kindness and friendliness $6,25 \%$; and justice and mercy $6,25 \%$. Based on the result of the analyzing process, honesty, courage, self-discipline and moderation, and unselfishness and sensitivity show the highest percentage of 12,5\%, which Erin Gruwell presents as the main character. Erin, as Ms. G exemplifies his students through their activities, always be honest, have self-discipline and moderation, unselfishness and sensitivity, and have courage whenever and wherever. She is a leading figure to exemplify good things to the students through her behaviors. Also, she chose to focus on dealing with problems that occurred in the lives of his students. Indeed, she chose to end her relationship with her husband.

\section{Teaching Strategy}

After analyzing the data found in "Freedom Writer" by Richard Lagravenese, the researcher can conclude the teaching strategy which emerges in the "Freedom Writer" is content-based instruction $30 \%$, theme-based instruction $20 \%$, experiential learning $10 \%$, the episode hypothesis $10 \%$, task-based teaching $30 \%$.

Content-based instruction and task-based teaching show the same percentage rate after the analysis, $30 \%$. Ms. G or Erin Gruwell, as the main character, is the leading figure in creating the situation. As a teacher in the Wilson school where the school contains many gangster children who need support and encouragement from the teachers.

Through the highest data, Erin tries to replay Marcus's statement without scolding him as a teacher. Instead, he continued with a new argument. She tries to discuss Homer's The Odyssey with the students. She describes the assured author of the 'Iliad' and the odyssey to discuss an epic author in ancient Greek literature. Moreover, she gives intrinsic motivation to the students. Also, she asks students to read. She tries to ask one of the students to practice reading sentences on the board to focus during the lesson. This indicates that she applies content-based instruction during the learning process.

Moreover, Erin decides for her student about reporting lesson of Anna Frank novel. She makes a new strategy that students should write a letter on paper. Therefore, she tries to make students report their life through a letter. She asks students to write about whatever students want, like a diary, the past, the present, the future. This indicates that she uses the strategy of task-based teaching.

On the other hand, Erin also invites students to talk with great people. She invites students to have dinner with great people in order to make conversation and interview about their great experiences. Each person talks about their story. This indicates that she teaches students to use the strategy of task-based teaching during learning activities.

Also, Erin asks students to make letters for Miep Gies as a writing assignment. She will send their letters to her. Indeed, she uses the letter in her learning activity during her English lesson. Besides radio, the letter is one medium that can be used for teaching activities in the classroom. She uses letters for students' writing assignments as a strategy of task-based teaching during the learning process.

\section{Conclusions}

The analysis has two objectives. The first objective is to analyze the educational value in the 'Freedom Writer,' and the second is to analyze the 'Freedom Writer' teaching strategy. Therefore, this section concludes the objectives: first, the researcher found educational values in the movie. Most of 
the data about educational values are shown by an English teacher named Erin as the main character. Thus, she shows that most educational values are in 'Freedom Writers' film through the value of being and giving. The data of educational values are 8 values of being such as honesty 12,5\%; courage $12,5 \%$; peace-ability $6,25 \%$; self-reliance and potential $6,25 \%$; self-discipline and moderation $12,5 \%$; and 8 value of giving such as: loyalty and dependability $6,25 \%$; respect $6,25 \%$; love $12,5 \%$; unselfishness and sensitivity 12,5\%; kindness and friendliness 6,25\%; and justice and mercy 6,25\%. Therefore, honesty, courage, self-discipline, love and unselfishness, and sensitivity are the most dominant educational values. Second, the researcher found teaching strategy in Freedom Writers film. As an English teacher, Erin applied some teaching strategies to students. Content-based instruction and task-based instruction are two strategies that Erin widely uses in learning English. Moreover, there are ten teaching strategies in the movie: content-based instruction 30\%, theme-based instruction $20 \%$, experiential learning $10 \%$, the episode hypothesis $10 \%$, task-based teaching $30 \%$. Therefore, the most dominant teaching strategies are content-based instruction and task-based teaching.

Therefore, based on the explanation results and conclusions, it can be concluded that this film can be a recommendation for teachers in applying good teaching strategies to their students. Also, this film can be a recommendation for teachers in improving student attitudes in their daily life through educational values. A teacher has a vital role in the success of his students. The success of teachers is mainly reflected in the positive changes experienced by their students. This positive change can be a variety of indicators, starting from students' understanding of the subject matter, students' enthusiasm in participating in the learning process, and most importantly, the extent to which students enjoy the learning process.

\section{References}

Abiola, O. O. F. (2013). Students' Perception of Teachers' Factors in the Teaching and Learning of English Language in Nigerian Secondary Schools. Journal of Educational and Social Research, 3(3), 173-179.

Endraswara, S. (2004). Metodologi Penelitian Sastra: Epistemologi, Model, Teori dan Aplikasi. Yogyakarta: Pustaka Widyatama.

Harumni, H. (2009). Strategi dan Model- Model Pembelajaran Aktif Menyenangkan. Yogyakarta: Fakultas Tarbiyah UIN Sunan Kalijaga.

Kitsner. (2015). The Role of Instructional Context and Teacher Beliefs. Vol 7 No 1 2015. Retrieved June 1, 2020.

Michael. (2009). Foundation of Special Education: An Introduction. Willey: Willey-Blackwell.

Novak, J. D. \& Gowin, D. B. (2002). Learning How to Learn. Cambridge University Press.

Saputra, H. (2012). Thesis: An Analysis of Educational Values in "Ranah 3 Warna Novel. STAIN Salatiga. 